\title{
A new species of the genus Ranunculus from Iran
}

\author{
Maneezheh Pakravan \\ Faculty of Science, Alzahra University, Dehe Vanak Str., Tehran, Iran \\ e-mail: pakravan@alzahra.ac.ir
}

Received 21 Jul 2012

Accepted 1 Nov 2012

\begin{abstract}
A new species of the genus Ranunculus named Ranunculus microflorus Pakravan (Ranunculaceae) from Iran is described and illustrated. The smooth fruit and erect stem differentiate it from $R$. repens L., the straight beak distinguishes it from $R$. caucasicus M.B., also the small flowers distinguish it from both species. Pollen grains were also studied and provided additional characters. The similarities between this species and other closely related species are also discussed.
\end{abstract}

KEYWORDS: pollen, Ranunculus, SEM

\section{INTRODUCTION}

Ranunculus L. (buttercups) is the largest genus in the Ranunculaceae, comprising approximately 600 species $^{1}$, distributed throughout the world. Most species are found in temperate to Arctic/sub Antarctic zones. In the tropics, they are rare and restricted to high mountain areas. Buttercups grow in various terrestrial or aquatic habitats from lowlands to high alpine zones. In Iran, they are represented by about 50 species $^{2}$, they flourish in the Irano-Turanian and Hyrcanian regions. Speciation and evolutionary success of buttercups are largely depended on polyploidy and hybridization. Some phylogenetic studies have been able to resolve taxonomic problems at the species level within the genus ${ }^{3-5}$.

In a project focused on the taxonomy and palynology of Ranunculus species in Iran, many herbarium specimens and living plants in the field were studied. The result of these studies is the discovery of a new species. The type specimens are preserved in the herbarium of Iran's Research Institute of Forests and Rangelands (TARI).

\section{MATERIALS AND METHODS}

Pollen of the $R$. microflorus and $R$. caucasicus were studied by light microscopy and scanning electron microscopy (SEM). The pollen samples were obtained from dry herbarium materials. Fully matured anthers were removed from the specimens and prepared by fixing in carnoy solution (it helps to clean the pollen surface). After one week the pollen grains were separated from the anther and were mounted in glycerin jelly and studied by light microscope. Measurements and morphological observations of pollen grains were performed by using minimum 20 pollen grains. For
SEM, the pollen grains were attached to the aluminium stubs with double sided cellophane tape and coated with gold. The specimens were examined with PHILIPS XL 30, LEO 400, and photographed.

Following selected specimens have examined: R. caucasicus: Persia, Azerbaijan, Arasbaran prot. Reg., Kaleibar to Makeidy, 2500-2650 m, Pakravan 5361 (Herbarium of Alzahra University: ALUH); Mazandaran, Sangdeh, 1600-1800 m, Assadi 73218 (TARI); Hamedan, Nahavand, road above Gamesab, 2500-3400 m, Assadi 75148 (TARI). Gilan province: Asalem to Khalkhal road, $1900 \mathrm{~m}$, Wendelbow \& Assadi 277889 (TARI).

R. repens: Persia, Azerbaijan, Arasbaran prot. Reg., 1200 m, Savabi \& Rauf 96 (TARI); Arasbaran, Ali Abad village to Escolu 1400 m, Pakravan 5450 (Herbarium of Alzahra University: ALUH); Mazandaran, Ramsar, Javaher-deh, 700 m, Rastipisheh 3707 (Herbarium of Alzahra University: ALUH).

\section{RESULTS AND DISCUSSION}

\section{Ranunculus microflorus Pakravan sp. nov.}

Type: Iran, Hamedan province, Nahavand, on the road to Nurabad, above Gamasab, Kuh-e Garin, 25003400 m, 27. September 1995, Assadi (TARI 75125). (holotype \& isotype TARI) (Fig. 1a-c, Fig. 2).

Species nova differt a Ranunculus caucasicus fructu rostro recto, a $R$. repens caulibus erectis (nec prostratis) et fructibus laevibus (nec punctatis).

Perennial plant, up to $28-30 \mathrm{~cm}$ in height. Rootstock short, profusely covered with fibres of dead leaves. Stem branched at the base, with semi apressed or spreading ciliate hairs. Radical leaves with long petioles, covered with semi apressed and spreading hairs. The blade broad-ovate in outline, twice 


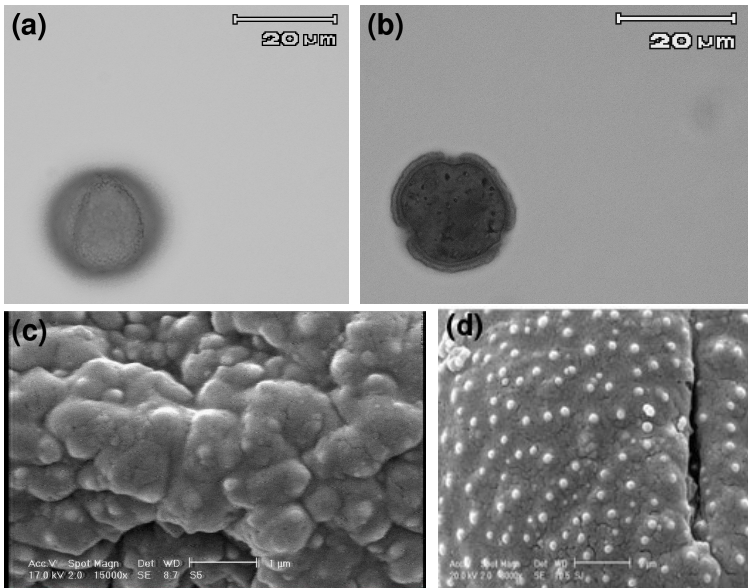

Fig. 1 Pollen grain of $R$. microflorus (Assadi 75125): (a) equatorial view, (b) polar view, (c) SEM picture of exin sculpturing. (d) R. caucasicus M.B. (TARI 277889a, Gilan province: Asalem to Khalkhal road, $1900 \mathrm{~m}$, Wendelbow \& Assadi), SEM picture of exin sculpturing. Scale bars: (a) and (b): $20 \mu \mathrm{m}$, (c) and (d): $1 \mu \mathrm{m}$.

tripartite; the central segment with long petiole or sub sessile, all segments deeply tripartite, with acute dentate lobes; the lower cauline leaves similar to the radical, the upper leaf sessile. All cauline leaves are tripartite almost to base. Peduncles are covered with sparse spreading hairs. Flowers have diameter of $0.7-1 \mathrm{~cm}$; sepals 5 , are oblong-elliptic, covered with spreading hair, $3 \times 2 \mathrm{~mm}$. Petals $5-6$, yellow, obovate, $3-4.5 \times 3.5 \mathrm{~mm}$. stamens numerous, filament 2-2.2 mm long, anther 1.7-2 mm long. Receptacle ovate- oblong, hairy. Achenes are glabrous, laterally compressed, 3-3.5 mm long, 2.3-3 $\mathrm{mm}$ broad, with veins along margins and $1.5-2 \mathrm{~mm}$ straight beak.

Etymology: The specific epithet of the new species refers to their very small flowers which are rare in the genus Ranunculus.

\section{Distribution}

The area from which $R$. microflorus was found is restricted to Hamedan province, on the southern slopes of the Garin Mountains.

Habitat ecology and phenology: $R$. microflorus grows on gravelous mountain slopes of limestone, among rocks between 3300 and $3400 \mathrm{~m}$ altitude. Flowering occurs late summer and fruiting probably early fall (Sept.). It should be mentioned that Garin Mountain is a very special environment where several new species of other genera are reported from this location.

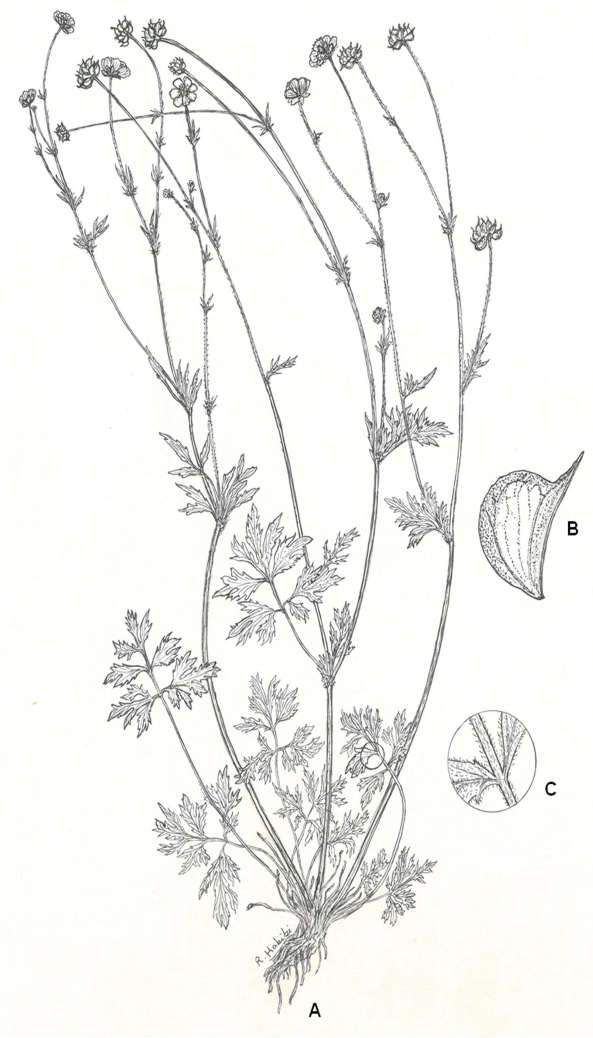

Fig. 2 R. microflorus. A: Habit; B: carpel; C: details of stem and leaf indumenta.

\section{Pollen characters}

$R$. microflorus is similar to $R$. caucasicus and $R$. repens in leaf shape, but it is different in having small flowers $(7-10 \mathrm{~mm}$, not $20-25 \mathrm{~mm}$ as in $R$. repens or $25-35 \mathrm{~mm}$ as in $R$. caucasicus), smooth fruit (not punctuate as in $R$. repens), straight beak (not curved as in $R$. caucasicus) and erected stem (not creeping as in $R$. repens). The characteristic features and differences among the related taxa are summarized in Table 1.

The pollen characters occurred in the $R$. acris type- $R$. monspeliacus group ${ }^{6}$. It is tricolpate, with narrow slightly sunken colpi, exin is verrucate, coarsely undulating (Table 2, Fig. 1).

The pollen characters are somewhat different from $R$. repens. Although both occur in $R$. acris type, but $R$. repens belongs to $R$. acris group. Pollen grain is pantocolpate and syncolpate in $R$. repens but it is tricolpate in $R$. microflorus. Moreover, the pollen grain is smaller than $R$. repens (Table 1). The pollen grains of $R$. caucasicus occurs in the $R$. acris type$R$. acris group. Both have tricolpate pollen, but in 
Table 1 Comparison of $R$. microflorus and its relative species.

\begin{tabular}{|c|c|c|c|c|c|c|c|}
\hline $\begin{array}{l}\text { Beak } \\
\text { shape }\end{array}$ & $\begin{array}{l}\text { Beak size } \\
(\mathrm{mm})\end{array}$ & $\begin{array}{l}\text { Fruit size } \\
\qquad(\mathrm{mm})\end{array}$ & Fruit shape & $\begin{array}{l}\text { Flower size } \\
\qquad(\mathrm{mm})\end{array}$ & Indumenta & $\begin{array}{l}\text { Leaf } \\
\text { segments }\end{array}$ & Species \\
\hline Straight & $1.7-2$ & $3-3.5 \times 2.5-3$ & $\begin{array}{l}\text { Smooth, ovate } \\
\text { with marginal vein }\end{array}$ & $0.7-10$ & $\begin{array}{l}\text { Glabrous or sparse } \\
\text { appress pilose }\end{array}$ & \multirow{3}{*}{$\begin{array}{l}\text { triangle with } \\
\text { acute dentate } \\
\text { with large } \\
\text { acute dentate } \\
\text { with large } \\
\text { acute-serrate } \\
\text { dentate }\end{array}$} & R. microflorus \\
\hline Straight & $0.7-1$ & $3-3.5 \times 2-2.5$ & $\begin{array}{l}\text { Punctuate, obovate } \\
\text { with vein }\end{array}$ & $20-25$ & $\begin{array}{l}\text { Glabrous or sparse } \\
\text { pilose }\end{array}$ & & $R$. repens \\
\hline Curved & $1-1.2$ & $2.5-3.5 \times 2-2.5$ & $\begin{array}{l}\text { Smooth, obovate } \\
\text { with marginal vein }\end{array}$ & $22-35$ & $\begin{array}{l}\text { Sparse to dense } \\
\text { patule pilose }\end{array}$ & & R. caucasicus \\
\hline
\end{tabular}

Table 2 Comparison of pollen characters of $R$. microflorus and its relative species.

\begin{tabular}{lccccl}
\hline Species & $P(\mu \mathrm{m})$ & $E(\mu \mathrm{m})$ & $P / E$ & Colpus & Sculpturing \\
\hline$R$. microflorus & 19.28 & $20-71$ & 0.93 & 3 & Coarsely undulate, microechinate \\
$R$. repens & $23-37$ & $26-32$ & $0.92-1.1$ & 5 & Coarsely undulate, microechinate \\
R. caucasicus & $24.31-28.12$ & $25-28.75$ & 0.97 & 3 & Verrucate, microechinate \\
\hline
\end{tabular}

$P$ : polar axis; $E$ : equatorial axis

$R$. caucasicus colpi are granulate inside, exin has perforation in the base of microechinae and exin is verrucate $^{7}$, not undulate as in $R$. microflorus. Pollen grain is larger than $R$. microflorus (Table 2).

Acknowledgements: The author would like to thank Research Council of Alzahra University for its financial support. My thanks also to Prof. Assadi for providing the Latin diagnosis and Mrs. Habibi for the illustration.

\section{REFERENCES}

1. Tamura M (1995) Angiospermae. Ordnung Ranunculales. Fam. Ranunculaceae. II. Systematic Part. In: Engler A, Hiepko P (eds) Die Natürliche Pflanzenfamilien, 2nd edn, 17a, IV. Duncker \& Humblot. Berlin, Germany, pp 223-519.

2. Iranshahr M, Rechinger KH, Riedl H (1993) Ranunculus. In: Rechinger K, H (eds) Flora Iranica Vol. 171 Ackademic Druck-und Verlagsanst. Graz, pp 127-94.

3. Paun O, Lehnebach C, Johansson JT, Lockhart P, Hörandl E (2005) Phylogenetic relationships and biogeography of Ranunculus and allied genera in the Mediterranean and the European alpine system (Ranunculaceae). Taxon 54, 911-30.

4. Emadzad K, Lehnebach C, Lockhart P, Hörandl E (2010) A molecular phylogeny, morphology and classification of genera of Ranunculeae (Ranunculaceae). Taxon 59, 809-28.

5. Rastipisheh S, Pakravan M, Tavassoli A (2011) Phylogenetic relationships in Ranunculus species (Ranunculaceae) based on nrDNA ITS and cpDNA trnL-F sequences. Progr Biol Sci 1, 41-7.

6. Clarke GCS, Punt W, Hoen PP (1991) The Northwest European pollen flora, 51, Ranunculaceae. Rev Palaeobot Palynol 69, 117-271.
7. Pakravan M, Rastipisheh S, Emadi N, Nemati S (2010) Study of pollen grains characters in the genus Ranunculus L. (Ranunculaceae) from Iran. Iran J Biol 23, 1-8. 